\title{
Effects of atmospheric pollutants on somatic and germ cells of Tradescantia pallida (Rose) D.R. HUNT cv. purpurea
}

\author{
BRUNO A. CRISPIM ${ }^{1}$, JULIANA C.V. SPÓSITO ${ }^{1}$, ROSILDA M. MUSSURY $^{1}$, \\ LEONARDO O. SENO ${ }^{2}$ and ALEXÉIA B. GRISOLIA ${ }^{1}$ \\ ${ }^{1}$ Faculdade de Ciências Biológicas e Ambientais/FCBA, Universidade Federal da Grande Dourados/UFGD, \\ Rodovia Dourados Itahum, Km 12, 79804-970 Dourados, MS, Brasil \\ ${ }^{2}$ Faculdade de Ciências Agrárias/FCA, Universidade Federal da Grande Dourados/UFGD, \\ Rodovia Dourados Itahum, Km 12, 79804-970 Dourados, MS, Brasil
}

Manuscript received on July 7, 2014; accepted for publication on July 29, 2014

\begin{abstract}
Anatomical alterations in leaves and DNA damage in cells caused by the accumulation of atmospheric pollutants can be measured by epidermal leaf analyses and Tradescantia micronuclei assay with early pollen tetrad cells. The present study examined the feasibility of using somatic and germ cells of Tradescantia pallida for biomonitoring purposes in the city of Dourados, state of Mato Grosso do Sul (MS), Brazil. Stomatal, micronucleus and epidermal leaf analyses were performed, using standard methodologies, on plants growing at three locations during six different time periods. Tradescantia micronuclei data were analyzed using SAS 9.2 software package and stomatal data were analyzed using SANEST software. Analyses of stomatal characteristics and micronuclei examination in T. pallida were found to be an efficient tool for monitoring atmospheric pollution. The micronucleus assay suggested that the number of micronuclei in early pollen tetrad cells was related to the intensity of vehicular traffic. Increased number of epidermal cells and stomata and increased stomatal density observed at locations with greater vehicular traffic are likely physiological responses of those plants to the increased gas exchange in highly polluted environments.
\end{abstract}

Key words: Biomonitoring, leaf anatomy, air pollution, micronuclei.

\section{INTRODUCTION}

Due to high concentration of industry and intense vehicular traffic, the atmosphere in large urban centers may contain many organic and inorganic mutagens and/or carcinogens (Colvile et al. 2001, Skov et al. 2001). Kardel et al. (2010) studied anatomical alterations in living organisms, especially plants, in urban areas exposed to atmospheric contaminants from vehicular traffic. Recently, a preliminary study by Crispim et al. (2012) correlated the increased

Correspondence to: Alexéia Barufatti Grisolia

E-mail: alexeiagrisolia@ufgd.edu.br number of micronuclei and the incidence of anatomical changes in $T$. pallida leaves with the level of pollution from vehicular traffic.

Biomonitoring can provide integrated information about the impact of poor air quality on the environment. Plants have frequently been used as bioindicators as they are stationary and often sensitive to the quality air pollutants of local environments (Calzoni et al. 2007, Nali and Lorenzini 2007). A number of anatomical parameters of plants, including their stomatal characteristics, have been found to be useful indicators of air quality 
in urban areas (Balasooriya et al. 2009, Kardel et al. 2010). Wuytack et al. (2010) evaluated the potential of using Salix alba L. ("salgueiro branco") leaves as bioindicators of air quality and concluded that the stomatal characteristics of this plant could successfully and accurately be used for that purpose.

The karyotype of Salix alba is composed of six pairs of relatively large chromosomes, making it a convenient instrument for karyotypic studies (Carvalho 2005). The Tradescantia Micronuclei Test (Trad-MCN) is a common technique used for evaluating genetic alterations and is an excellent indicator of chromosome damage caused by chemical substances in the environment. This test is considered a basic tool due to its high sensitivity of Tradescantia pallida to genotoxic substances (Crispim et al. 2012).

Several authors confirmed the efficiency of $T$. pallida leaves in monitoring programs (Isidori et al. 2003, Guimaraes et al. 2004, Meireles et al. 2009). Anatomical analyses of leaves and Trad-MCN of early pollen tetrad cells assess the structural changes and damages to the genetic material caused by atmospheric pollutants (Ferreira et al. 2003, Andrade Júnior et al. 2008).

The effect of pollutants on the epidermal leaf cells in Tradescantia in Dourados, state of Mato Grosso do Sul (MS), Brazil, were observed from a single collection in August 2010 (Crispim et al. 2012). To address the seasonal variations in leaf anatomy and the effects of air pollution, the present study evaluated the correlation between micronuclei in early pollen tetrad cells and leaf epidermal cells, with the emphasis on stomata, and the level of air pollution from vehicular traffic in different seasons of the year in the city of Dourados, state of Mato Grosso do Sul (MS), Brazil.

\section{MATERIALS AND METHODS}

STUDY AREA

Three flowerbeds containing T. pallida (Rose) D.R. Hunt cv. purpurea under direct sunlight and without artificial irrigation were selected in the city of Dourados-MS at locations with distinct levels of motor vehicle flux: 1) Rua Hayel Bom Faker (S 22 ${ }^{\circ} 14^{\prime} 86^{\prime \prime} \mathrm{W} 054^{\circ} 48^{\prime} 28^{\prime \prime}$ ), with intense traffic (approximately 1900 vehicles per hour); 2) Rua Ponta Porã (S $22^{\circ} 13$ '13"W $054^{\circ} 48^{\prime} 58^{\prime \prime}$ ), with medium level of traffic (approximately 500 vehicles per hour); and 3) Cidade Universitária (S $22^{\circ} 11^{\prime} 796^{\prime \prime}$ W $\left.054^{\circ} 56^{\prime} 025^{\prime \prime}\right)$, an open area with low traffic (approximately 20 vehicles per hour).

\section{COLLECTION OF STUdied MATerial}

Ten leaves and 15 young inflorescences of T. pallida were collected every month at 7:00 AM, from April to September, 2011 from the three locations described above.

\section{ANATOMICAL STUDIES}

Abaxial and adaxial impressions (made using Super Bonder ${ }^{\circledR}$ glue) of the leaf epidermis were taken in the median region of the leaf blade of the specimens. Sixty slides were made at each sampling point over the six-month sampling period. Collected material was observed under a light microscope, and photographed with a coupled digital camera with the aid of Moticam 2300 3.0MP live Resolution image-capturing software.

The stomatal indices and stomatal densities were evaluated by counting the epidermal cells and stomata $\left(\right.$ per $\mathrm{mm}^{2}$ ) in one field per slide. The stomatal index at each collection point at each collection period was calculated using the Salisbury formula, following Wilkinson (1979). The stomatal density was calculated by determining the number of stomata in $1 \mathrm{~mm}^{2}$, projected onto a flat surface using a Zeiss microscopic projection system.

TRAD-MN ANALYSES

Trad-MCNs were detected by fixing the inflorescences in Carnoy solution (3:1 alcohol to acetic acid) for 24 hours, and subsequently preserving them in $70 \%$ ethanol. Inflorescences 
approximately $0.5 \mathrm{~cm}$ in diameter were selected and the tetrads were prepared for viewing following the methodology proposed by Crispim et al. (2012).

\section{STATISTICAL ANALYSES}

Statistical analyses of the observed anatomical characteristics were performed on data collected from the three collection points during the six collection periods. Each sample of 60 slides was divided into six subsamples, with an average of 10 observations (each representing one repetition). The measurements were compared using the Tukey test at the 5\% probability level (Snedecor and Cochran 1989).

The Trad-MCN analyses were performed using SAS 9.2 software package (SAS 2000).
The Shapiro-Wilk test was used to verify the normality of the residuals, and Bartlett test to examine homogeneity among the variances. MCN data that fulfilled the presuppositions (normality and homogeneity) were submitted to analysis of variance and posterior comparison of the averages by the Tukey test at the 5\% probability level. The Pearson Test was used to calculate correlations between the variables at the 5\% significance level.

\section{RESULTS}

The leaves of Tradescantia pallida are hypostomatic with diacytic stomata (Fig. 1). Both the abaxial and adaxial faces of the epidermis have polygonal cells with straight walls.

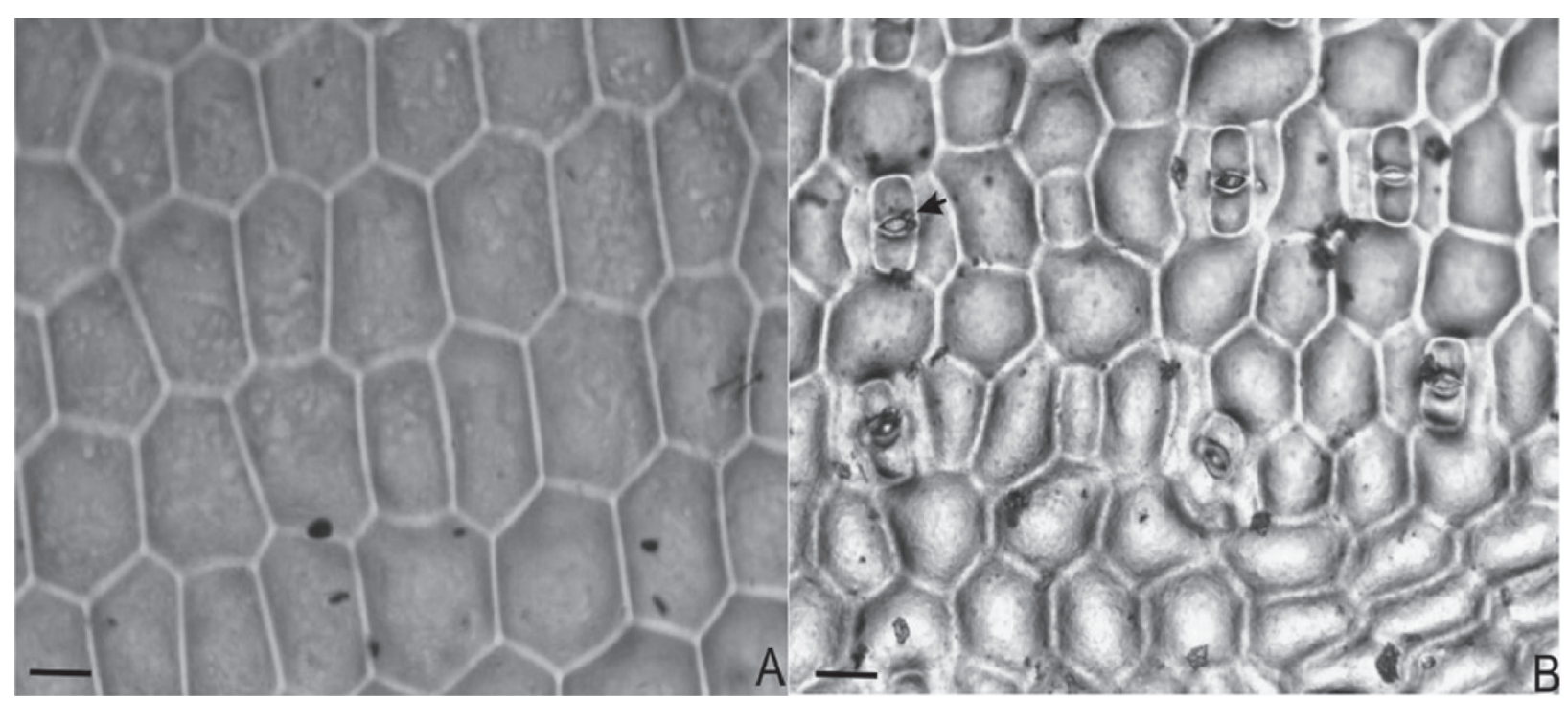

Fig. 1 - Epidermis of Tradescantia. (a). Adaxial face. (b). Abaxial face (arrow indicates a stomata). Scale bar $=50 \mu \mathrm{m}$.

The results of the analyses of variance of the correlation between the variables: points, periods, and periods/points of leaf characteristics and the total numbers of micronuclei (MCN) were analyzed for the sampling points and the collection times (Table I).

Comparisons between the variables that demonstrated significant differences among the sampling points are given in Figure 2.
Stomatal index data did not demonstrate significant differences between different sampling points or between different collection periods. Analyses of the correlation between these two variables, however, indicated significant difference in stomatal densities in terms of the three sampling points, collection periods, and collection points/ times (Table I). 
TABLE I

Variance analysis data of the leaf characteristics analyzed and average numbers of micronuclei (MCN), considering the sampling points and the collection periods and observed in Tradescantia pallida

\begin{tabular}{|c|c|c|c|c|c|c|}
\hline \multirow{2}{*}{$\begin{array}{l}\text { Cause of the } \\
\text { variation }\end{array}$} & \multicolumn{4}{|c|}{ leaf characteristics } & \multicolumn{2}{|c|}{$\begin{array}{l}\text { Average numbers of } \\
\text { MCN }\end{array}$} \\
\hline & $\begin{array}{c}\text { Numbers of } \\
\text { epidermal cells }\end{array}$ & $\begin{array}{l}\text { Numbers of } \\
\text { stomata }\end{array}$ & $\begin{array}{c}\text { Stomatal index } \\
(\%)\end{array}$ & $\begin{array}{c}\text { Stomatal density } \\
\left(\mathrm{mm}^{2}\right)\end{array}$ & $D F$ & $\begin{array}{c}\text { root mean square } \\
\text { MCN }\end{array}$ \\
\hline Points & $2.46^{*}$ & $0.06^{*}$ & 1.23 & $72.95^{*}$ & 2 & $6126.81 * * *$ \\
\hline Periods & 0.03 & 0.00 & 0.23 & $28.04^{*}$ & 5 & $64.98^{\mathrm{NS}}$ \\
\hline Points x Periods & 0.08 & 0.01 & $2.47 *$ & $10.07 *$ & 10 & $282.77 *$ \\
\hline $\mathrm{CV}(\%)$ & 4.39 & 7.38 & 6.48 & 7.29 & 21.96 & \\
\hline
\end{tabular}

Significance: $*(\mathrm{P}<0.5), * *(\mathrm{P}<0.1)$ and $* * *(\mathrm{P}<0.001)$; Not significant: ${ }^{\mathrm{NS}}(\mathrm{P}>0.5) . \mathrm{CV}-$ Coefficient of variation. DF - degrees of freedom.

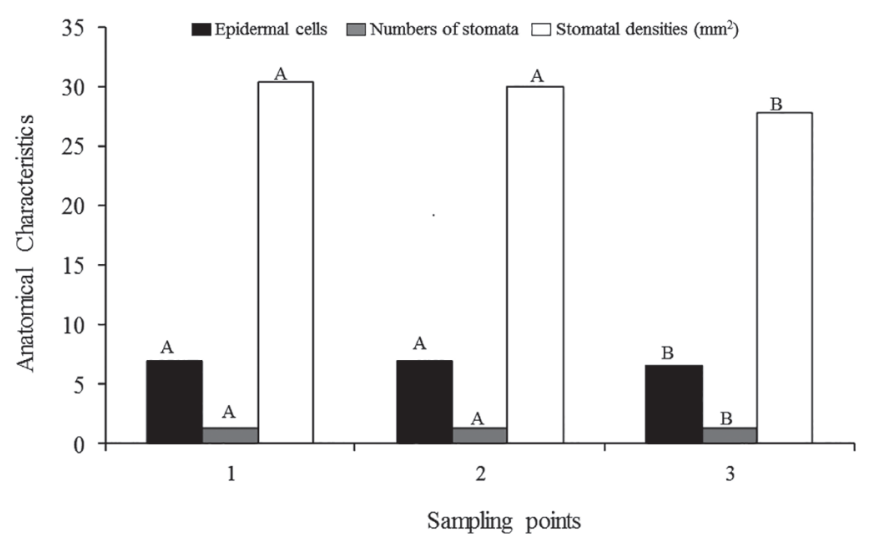

Fig. 2 - Numbers of epidermal cells, numbers of stomata, and stomatal densities of the leaves of $T$. pallida at the three sampling points. (Averages of the anatomical characteristics at the different sampling points followed by the same letter do not significantly differ according to the Tukey test at a $5 \%$ level of probability).

Only point 3 demonstrated significant differences in analyzed leaf variables. Analysis of variance indicated that in areas with greater vehicular traffic (points 1 and 2), the number of epidermal cells and stomata and the stomatal densities were higher (Fig. 2).

Stomatal density was the highest at points 1 and 2 during August and September, and at point 3 in September, coinciding with reduced rainfall (Fig. 3).

Large numbers of MCN were observed in September, and the smallest numbers in June; significant differences were observed in terms of the quantities of $\mathrm{MCN}$ variables between points 1, 2, and 3 (Table II). Pearson simple correlation analyses of the characteristics analyzed indicated a positive association of $0.10(p<0.01)$ for $\mathrm{MCN}$.

\section{DISCUSSION}

Atmospheric pollution is becoming a worldwide concern, particularly in regions with intense motor vehicle traffic. Many different components found in contaminated air (Isidori et al. 2003) have been associated with genotoxic activity and modifications of leaf structures in a number of studies (DuFour et al. 2005, Cupr et al. 2006), demonstrating the urgent need for improved air quality and public health efforts (Alves 2008). 


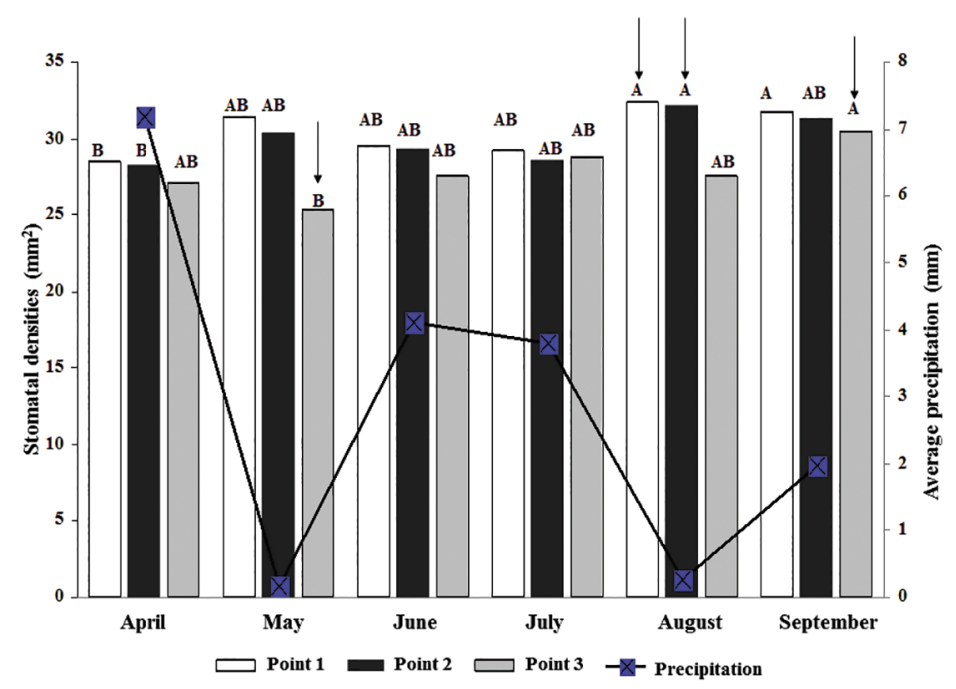

Fig. 3 - Average precipitation $(\mathrm{mm})$ and the stomatal density of Tradescantia pallida leaves collected at the three sampling points during different periods of the year. (The averages of each point followed by the same letter did not differ significantly at the different collection times according to the Tukey test at a 5\% level of probability). Arrows indicate the periods of less rainfall.

TABLE II

Average numbers of micronuclei observed in tetrads of Tradescantia pallida at the three sampling points in relation to the different collection periods, indicating their statistical differences as determined by the Tukey test at a $5 \%$ level of significance.

\begin{tabular}{cccc}
\hline $\begin{array}{c}\text { Collection } \\
\text { period }\end{array}$ & $\begin{array}{c}\text { Point 1 } \\
(\sim 1387 \\
\text { vehicles/h) }\end{array}$ & $\begin{array}{c}\text { Point } 2 \\
(\sim 1132 \\
\text { vehicles/h) }\end{array}$ & $\begin{array}{c}\text { Point 3 } \\
(\sim 18 \\
\text { vehicles/h) }\end{array}$ \\
\hline April & $37.2 \mathrm{aA}$ & $22.2 \mathrm{bA}$ & $7.4 \mathrm{cA}$ \\
May & $37.4 \mathrm{aA}$ & $25.4 \mathrm{bA}$ & $8.2 \mathrm{cA}$ \\
June & $35 \mathrm{aA}$ & $26.6 \mathrm{bA}$ & $7 \mathrm{cA}$ \\
July & $36.6 \mathrm{aA}$ & $28.8 \mathrm{bA}$ & $9.4 \mathrm{cA}$ \\
August & $32.6 \mathrm{aA}$ & $30.6 \mathrm{aA}$ & $9 \mathrm{bA}$ \\
September & $38.4 \mathrm{aA}$ & $25.4 \mathrm{bA}$ & $7.4 \mathrm{cA}$ \\
\hline
\end{tabular}

Averages followed by the same lower class letters along the same line, or by the same upper-class letters in the same column do not differ significantly.

Significant differences in stomatal indices were not noted at the three different collection points. However, the stomatal index was significantly lower at point 3 in May. It is possible that the lack of significant variation in this parameter during the survey was due to the intrinsic nature of this characteristics, as observed by Salisbury (1927).
However, Pompelli et al. (2010) expressed doubts in the lack of alteration of the stomatal index, as a number of studies have presented contrary results (Pandey et al. 2003, Liao et al. 2005, Miyazawa et al. 2006, Zhao et al. 2006). Results similar to those of the present work were reported by Alves et al. (2001) in their study of leaf anatomy of Tradescantia in areas with different degrees of atmospheric pollution in the city of São Paulo, Brazil.

The differences in stomatal density between points 1 and 2 in the present study showed that this characteristic is an important bioindicator, as the gases that penetrate the plant's leaves through the ostiole can cause alterations in their physiology, metabolism, ultra structure, and/or cellular structures. Alves et al. (2008) observed that stomatal density in Eugenia uniflora L. varied between specimens collected at locations with different degrees of air pollution. Their results indicated that individuals growing at sites with the highest level of pollution had the highest stomatal density. Similar increase in stomatal density has been reported in other plant species exposed to 
both air pollution (Kardel et al. 2010, Crispim et al. 2012) and water deficits (Larcher 2000).

Statistically significant reductions in stomatal size in hybrid clone 4430 of Tradescantia reported by Alves et al. (2001) could be attributed to pollution effects, suggesting that this anatomical parameter is a potential structural bioindicator of pollution effects.

Our results indicated that $T$. pallida plants growing in areas with high vehicular fluxes demonstrate greater number of epidermal cells and higher stomatal densities (Fig. 2). These observations indicated that the pollution levels in those localities were unfavorable to normal physiological development, and that the increase in the number of stomata is essential for effective gas exchange under adverse conditions.

Genetic damage in the form of mutations in Tradescantia was associated with high automobile traffic (Ferreira et al. 2003, Andrade Júnior et al. 2008). Similarly, the number of micronuclei observed in the present study was proportional to the vehicular flux, indicating that air pollutants had clastogenic effects on chromosomes in plant cells, resulting in large quantities of micronuclei in specimens growing near sites with intense traffic (Crispim et al. 2012).

Point 1 was situated near an access road, which was also a main route for the city exit with an electronic checkpoint where the vehicles would slow down and then accelerate, a process that released even larger quantities of combustion products. The smallest number of micronuclei was observed at Point 3 where traffic was less intense and the landscape more open. Similar results were observed in previous study indicating that open areas allow greater ventilation, disperse pollution, and decrease genetic damage (Alves et al. 2003).

Trad-MCN testing in $T$. pallida has been proven to be efficient for analyzing genotoxicity (micronuclei formation) and for biomonitoring atmospheric pollution in urban environments
(Oliveira et al. 2007). Our results indicated that air pollution is most likely responsible for the somatic cells alterations found in T. pallida, and that these plants responded in quantifiable manners to the effects of pollution. Experiments involving controlled exposure of active as well as passive agents under standard soil conditions would help reveal the full potential of T. pallida as a bioindicator of airborne urban pollutants.

In conclusion, the results of the analysis of micronuclei in early pollen tetrad cells and changes in epidermal cells, call for continuous monitoring of the urban air quality in different seasons of the year in order to evaluate the risks to affected human populations, and provide subsidies for the elaboration of public policies that could minimize exposure to atmospheric pollutants. Future studies evaluating structures and tissue thickness leaf are relevant for the analysis of environmental biomonitoring.

\section{ACKNOWLEDGMENTS}

The authors would like to thank the Universidade Federal da Grande Dourados for and Coordenação de Aperfeiçoamento de Pessoal de Nível Superior (CAPES).

\section{RESUMO}

As alterações anatômicas em folhas e danos no DNA de células causadas pelo acúmulo de poluentes atmosféricos podem ser mensuradas por meio de análises de epiderme foliar e ensaio de micronúcleos em Tradescantia com células de pólen jovens. O presente estudo examinou a viabilidade do uso de células somáticas e germinativas de Tradescantia pallida para fins de biomonitoramento na cidade de Dourados, Estado do Mato Grosso do Sul (MS), Brasil. Análises estomáticas, micronúcleos e células de epiderme foliar foram realizadas utilizando metodologias padronizadas em plantas em crescimento em três locais durante seis períodos de tempo diferentes. Dados de micronúcleos em Tradescantia foram analisados usando 
SAS 9.2 pacote de software e dados de estômatos foram analisados usando o software SANEST. As análises de características estomáticas e a verificação de micronúcleos em T. pallida foram encontradas para ser um instrumento eficaz no monitoramento da poluição atmosférica. $\mathrm{O}$ ensaio de micronúcleo sugeriu que o número de micronúcleos em células de pólen jovens foi relacionado com a intensidade do tráfego veicular. $\mathrm{O}$ aumento do número de células epidérmicas e estômatos e o aumento da densidade estomática observada em locais com maior tráfego veicular são prováveis respostas fisiológicas dessas plantas para o aumento da troca de gases em ambientes altamente poluídos.

Palavras-chave: Biomonitoramento, anatomia foliar, poluição do ar, micronúcleos.

\section{REFERENCES}

Alves ES, Giusti PM, Domingos M, SAldiva PHN, GuIMARÃES ET AND LoBO DJA. 2001. Anatomic studies on Tradescantia hibrid clone 4430 leaves: changes caused by urban Air pollution. Rev Bras Bot 24: 567-576.

Alves ES, Pedroso ANV, Domingos M, Guimarães ET AND SALDIVA PHN. 2003. Indoor biomonitoring of mutagenic potential of air in laboratories and herbarium of Instituto de Botânica using the Trad-MCN bioassay. Hoehnea 30: 89-94.

ALVES ES, TRESMONDI F AND LONGUI EL. 2008. Leaf anatomy of Eugenia uniflora L. (Myrtaceae) in urban and rural environments, São Paulo State, Brazil. Acta Bot Bras 22: 241-248.

ANDRADE JÚNIOR SJ, SANTOS JÚNIOR JCS, OlIVEIRA JL, CERQueIRA EMM AND MEIRELES JRC. 2008. Micronuclei in tetrads of Tradescantia pallida (Rose) Hunt. cv. purpurea Boom: genetic changes caused by urban air pollution. Acta Sci Biol Sci 30: 295-301.

BALASOORIYA BLWK, SAMSON R, MBIKWA F, Vitharana UWA, BOECKX P AND VAN MEIRVENNE M. 2009. Biomonitoring of urban habitat quality by anatomical and chemical leaf characteristics. Environ Exp Bot 65: 386-394.

CAlzoni GL, Antognoni F, PARi E, Fonti P, Gnes A And SPERANZA A. 2007. Active bio-monitoring of heavy metal pollution using Rosa rugosa plants. Environ Pollut 149: 239-245.

CARVAlHo HA. 2005. Use of Tradescantia to monitor the clastogenic effects of ionizing radiation. Radiol Bras 38 : 459-462.

COLVILE RN, Hutchinson EJ, Mindell JS AND WARREN RF. 2001. The transport sector as a source of air pollution. Atmos Environ 35: 1537-1565.
Crispim BA, VAini JO, Grisolia AB, TeiXeira TZ, Mussury RM AND SENO LO. 2012. Biomonitoring the genotoxic effects of pollutants on Tradescantia pallida (Rose) D.R. Hunt in Dourados, Brazil. Environ Sci Pollut Res 19: 718-723.

Cupr P, KlÁnová J, Bartos T, Flegrová Z, KohouteK J AND HolOUBEK I. 2006. Passive air sampler as a tool for long-term air pollution monitoring: Part 2. Air genotoxic potency screening assessment. Environ Pollut 144: 406413.

Dufour G, BoOne CD And Bernath PF. 2005. First measurements of CFC-113 and HCFC-142b from space using ACE-FTS infrared spectra. Geo Res Letters 32: L15S09.

FErreira MI, Rodrigues GS, DOMINGOS M AND SALdiva PHN. 2003. In situ monitoring of mutagenicity of air pollutants in São Paulo city using Tradescantia-SHM bioassay. Braz Arch Biol Techn 46: 253-258.

Guimarães ET, Macchione M, Lobo DJ, Domingos M AND SALDIVA PHN. 2004. Evaluation of the mutagenic potential of urban air pollution in São Paulo, Southeastern Brazil, using the Tradescantia stamen-hair assay. Environ Toxicol 19: 578-584.

ISIDORI M, FERRARA M, LAVORGNA M, NARDELLI A AND PARRELLA A. 2003. In situ monitoring of urban air in Southern Italy with the tradescantia micronucleus bioassay and semipermeable membrane devices (SPMDs). Chemosphere 52: 121-126.

Kardel F, Wuyts K, Babanezhad M, Vitharana UWA, WUYTACK T, POTTERS G AND SAMSON R. 2010. Assessing urban habitat quality based on specific leaf area and stomatal characteristics of Plantago lanceolata L. Environ Pollut 158: 788-794.

LARCHER W. 2000. Ecofisiologia Vegetal. São Carlos: RiMa, $530 \mathrm{p}$.

LiAO JX, CHANG J AND WANG GX. 2005. Stomatal density and gas exchange in six wheat cultivars. Cereal Res Commun 33: 719-726.

Meireles J, Rocha R, Neto AC And Cerqueira E. 2009. Genotoxic effects of vehicle traffic pollution as evaluated by micronuclei test in Tradescantia (Trad- MCN). Mutat Res 675: 46-50.

MiYAZAWA SI, LiVINGSTON NJ AND TURPIN DH. 2006. Stomatal development in new leaves is related to the stomatal conductance of mature leaves in poplar (Populus trichocarpa $\times$ P. deltoids). J Exp Bot 57: 373-380.

NALI C AND LORENZINI G. 2007. Air quality survey carried out by schoolchildren: an innovative tool for urban planning. Environ Monit Assess 131: 201-210.

Oliveira DS, CRNKOVIC PM, Viana VGF, SALdiva PHN, Domingos M AND PAGLIUSO JD. 2007. Indoor biomonitoring of mutagenic potential of air pollutants from emission incense using the Tradescantia stamen hair assay. J Braz Soc Ecotoxicol 2: 173-178.

PANDEy S, Kumar S AND NAGAR PK. 2003. Photosynthetic performance of Ginkgo biloba L. grown under high and low irradiance. Photosynthetica 41: 505-511. 
POMPELLI MF, BARATA-Luís RM, VITORINO HS, GONÇALVES ER, Rolim EV, SANTOS MG, ALMEIDA-CORTEZ JS, FERrEIRA VM, LEMOS EE AND ENDRES L. 2010. Photosynthesis, photoprotection and antioxidant activity of purging nut under drought deficit and recovery. Biomass Bioenerg 34: 1207-1215.

SALISBURY EJ. 1927. On the causes and ecological significance of stomatal frequency, with special reference to the woodland flora. Phil Trans R Soc Lond B 216: 1-65.

SAS InSTITUTE 2000. SAS/STAT software: changes and enhancement through release 9.2. SAS Institute, Cary.

SKOV H, HANSEN AB, LORENZEN G, ANDERSEN HV, LøFSTRøM P AND Christensen CS. 2001. Benzene exposure and the effect of traffic pollution in Copenhagen, Denmark. Atmos Environ 35: 2463-2471.
SNEDECOR GW AND COCHRAN GW. 1989. Statistical methods. Iowa. State University. 503 p.

WiLKINSON HP. 1979. The Plant Surface. In Metcalfe CR and Chalk L (Eds), Anatomy of the Dicotyledons. Oxford, Clarendon Press. Vol. 1: 97-165.

WUYTACK T, VERHEYEN K, WUYTS K, KARDEL F, ADRIAENSSENS S AND SAMSON R. 2010. The potential of biomonitoring of air quality using leaf characteristics of white willow (Salix alba L.). Environ Monit Assess 171: 197-204.

ZHAO X, YANG Y, SHEN Z, ZHANG H, WANG G. AND GAN Y 2006. Stomatal clustering in Cinnamomum camphora. S Afr J Bot 72: 565-569. 